\title{
Ecological genetics of Norwegian Daphnia. III. Clonal richness in an Arctic apomictic complex
}

\author{
ANDERS HOBAEK*, LAWRENCE J. WEIDER $†$ \& HANS GEORG WOLF† \\ Museum of Zoology, Department of Animal Ecology, University of Bergen, Muséplass 3, N-5007 Bergen, Norway
}

\begin{abstract}
Arctic pond populations of Daphnia pulex on Svalbard, off the north Norwegian coast, were assayed for clonal richness. A total of 21 unique clones from 20 ponds were distinguished by allozyme electrophoresis at seven enzyme loci. Seventeen clones showed unbalanced electromorph banding patterns at certain enzyme loci, which suggests that they are polyploids. Each pond harboured an average of 1.7 clones (range 1-4). The most common clone was found in six ponds, and accounted for 23.5 per cent of all animals screened. Most clones were found only in one or two ponds. No discernible geographical patterns could be detected in clonal distributions, and all sampled areas held unique clones. The data suggest that our sampling effort has uncovered only a small subset of a much larger array of clones on this remote arctic archipelago, and indicates that the genetic structure of this apomictic complex is one of the most fragmented among asexual organisms.
\end{abstract}

Keywords: biogeography, clonal richness, Daphnia, parthenogenesis, polyploidy, Svalbard.

\section{Introduction}

The presence of substantial genetic (clonal) variation in populations of asexual organisms (Parker, 1979; Bell, 1982) has led to numerous attempts at explaining the mechanism maintaining clonal coexistence in these populations (Futuyma et al., 1981; Lynch, 1984; Ayre, 1987; Christensen et al., 1988), which can be directly related to the study of the evolutionary advantages/ disadvantages of sexual reproduction (Bell, 1982).

Recent studies have revealed that pond populations of members of the freshwater microcrustacean, Daphnia pulex complex in North America contain high levels of genetic (clonal) diversity (Lynch, 1983; Hebert \& Crease, 1983; Weider \& Hebert, 1987a; Hebert et al., 1988), which appear to be maintained by both biotic (Wilson \& Hebert, 1992) and abiotic (Weider \& Hebert, 1987b) factors. Contrary to earlier expectations of an attenuation of clonal diversity with increasing latitude (Weider et al., 1987), arctic populations contain high levels of genetic (clonal) richness.

*Correspondence and present address: Norwegian Institute for Water Research, Thormøhlensgt. 55, N-5008 Bergen, Norway. †Max-Planck-Institut für Limnologie, Abt. Okophysiologie, Postfach 165, D-2320 Plön, Germany.

‡Deceased 1990.
The predominant reproductive mode in this complex is via obligate parthenogenesis (Hebert et al., 1988), particularly in the arctic (Weider et al., 1987), while cyclic parthenogenesis prevails south of the Laurentian Great Lakes (Innes et al., 1986; Hebert et al., 1988). Within this broad geographic range, this species complex contains large numbers of electrophoretically distinct clones, which probably number in the tens of thousands. A fraction of these clones are polyploids, although this is not a prerequisite for their asexual reproductive mode (Beaton \& Hebert, 1988). Molecular evidence indicates that the asexual complex has polyphyletic origins (Crease et al., 1989; Hebert et al., 1989), i.e. obligately parthenogenetic clones have arisen many times from cyclically parthenogenetic ancestors.

Although members of the Daphnia pulex complex have an even broader distribution in the Old World, much less is known about variation in their reproductive mode and clonal diversity outside North America (Ward \& Geissler, 1988). Obligate asexuality was, in fact, first reported from the arctic islands of Svalbard (Olofsson, 1918), and is generally regarded as the predominant breeding mode in the arctic, based both on the scarcity or absence of males in arctic populations (Haney \& Buchanan, 1987), and in the obligately 
parthenogenetic production of diapausing eggs (Weider \& Hebert, 1987b; Weider et al., 1987).

The present study was undertaken to investigate clonal richness of members of the $D$. pulex complex in a remote, arctic area. Svalbard is an archipelago situated about $1000 \mathrm{~km}$ north of the European mainland, and about $500 \mathrm{~km}$ east of Greenland. If clonal diversity in Svalbard is comparable to that of North America, then one must consider the possibility that this apomictic complex extends over a vast range in a circumpolar fashion, and includes all of Siberia, the arctic islands, Iceland, Greenland and most of North America.

\section{Materials and methods}

Sampling was conducted on Spitsbergen (the largest island of the Svalbard archipelago) in August 1987. The field work was based at the Norwegian Polar Research Institute's research station at $\mathrm{Ny}-\AA$ Alesund on the western coast $\left(79^{\circ} 55^{\prime} \mathrm{N}, 11^{\circ} 56^{\prime} \mathrm{E}\right)$. Twenty ponds were successfully sampled. Seventeen of them were situated along the Kongsfjord or its vicinity (Fig. 1). Along the Isfjord, another three ponds were sampled. Most ponds were less than $1 \mathrm{~m}$ deep, and all are situated along the coastline less than $2 \mathrm{~km}$ from the sea at altitudes below $50 \mathrm{~m}$ a.s.l. Some morphometric and physico-chemical characteristics of the ponds are given (Table 1).

Animals were collected and transported live in thermos bottles to the laboratory, where they were sorted individually into the wells of microtiter plates within $12 \mathrm{~h}$ of collection. Each animal was placed in 10 $\mu 10.001 \mathrm{~m}$ mercaptoethanol solution, and frozen at $-80^{\circ} \mathrm{C}$ for later electrophoretic analysis. Replicate samples from each pond were preserved in formalin for later identification and morphological analysis. Surface water samples from each pond were analysed for conductivity $\left(\mu \mathrm{S} \mathrm{cm} \mathrm{cm}^{-1}\right)$ and short-wave light absorption (at 254 and $384 \mathrm{~nm}$ ).

Electrophoresis was undertaken using cellulose acetate gels (Helena Laboratories, Beaumont, TX), following the procedures of Hebert \& Beaton (1989). The following enzymes were screened: aldehyde oxidase $(\mathrm{AO}) ;$ glutamate-oxaloacetate transferase (GOT); lactate dehydrogenase (LDH); malate dehydrogenase (MDH); mannose-phosphate isomerase (MPI); phosphoglucose isomerase (PGI); and phosphoglucomutase (PGM). For the remainder of the paper, the term 'electrophoretic clone' will be used to designate unique seven-locus genotypes as detected by electrophoresis. The use of marker animals propagated from clones isolated from the Canadian arctic allowed gel scoring and allele designations to be comparable with results from Canada (Weider \& Hebert, 1987a,b; Weider et al., 1987). Data were obtained on a total of 1316 animals. In addition, we included 57 animals from pond E, which was resampled in July 1991.

Genetic relatedness between electrophoretic clones was analysed by computing a simple matching coefficient between each pair of clones (Innes et al., 1986; Weider et al., 1987); we assumed that all clones were tetraploid based on the criteria of Weider et al. (1987). Coefficients of similarity were converted to Euclidean distances by taking the square root of the complement of the coefficient (Sneath \& Sokal, 1973). The genetic distance matrix was then subjected to a principal coordinate analysis (Gower, 1966), using the NTSYSPC program (Rohlf, 1990).

A Mantel test (Mantel, 1967) was used to analyse for geographic patterns in clonal distribution, by first constructing a similarity matrix between the clonal arrays in each pond, based on Sorensen's index (Pielou, 1984), and then correlating this similarity matrix with a matrix of distances $(\mathrm{km})$ between ponds.

\section{Results}

In the 20 ponds, we detected a total of 20 distinct electrophoretic clones in 1987 (Table 2). One additional electrophoretic clone was found in the 1991 sample from Pond E, for a total of 21 clones. Seventeen of the detected clones showed 'unbalanced' electromorph banding patterns (Weider et al., 1987) at one enzyme locus (16 at $P G M$ and 1 at PGI, Table 2), suggesting that they are polyploids (Beaton \& Hebert, 1988 ). Heterozygosity values (measured as the fraction of heterozygous loci) ranged from 0 to 0.571 $($ mean $=0.327$, S.E. $=0.030)$. Svalbard animals showed extensive allelic overlap with animals from the Canadian arctic. Nearly all the alleles from Svalbard are also present at Churchill, Manitoba (Weider \& Hebert, 1987a) and/or Igloolik, N.W.T. (Weider et al., 1987), with the exceptions of the slow $(0)$ alleles observed at the $L D H$ and $M D H$ loci (Table 2).

The clonal composition of each pond is given (Table $3)$. On average, each pond held 1.7 electrophoretic clones (range: $1-4$, S.E. $=0.9$ ). There is no readily apparent pattern in the geographical distributions of clones or clonal groups. All the investigated areas held unique electrophoretic clones, although the more common clones occurred in several areas. Clone 1 was most common; it occurred in six ponds and constituted 23.5 per cent of all animals sampled. On average, each electrophoretic clone occurred in 1.6 ponds $($ S.E. $=0.25)$, and 13 clones were detected only in one pond each (Table 2). The Mantel test detected no significant geographical patterning (matrix correlation 
Fig. 1 Map showing the location of sampling areas (shaded dots) on Spitsbergen, Svalbard. The ponds located within each area are given, with designations as in Table 1.

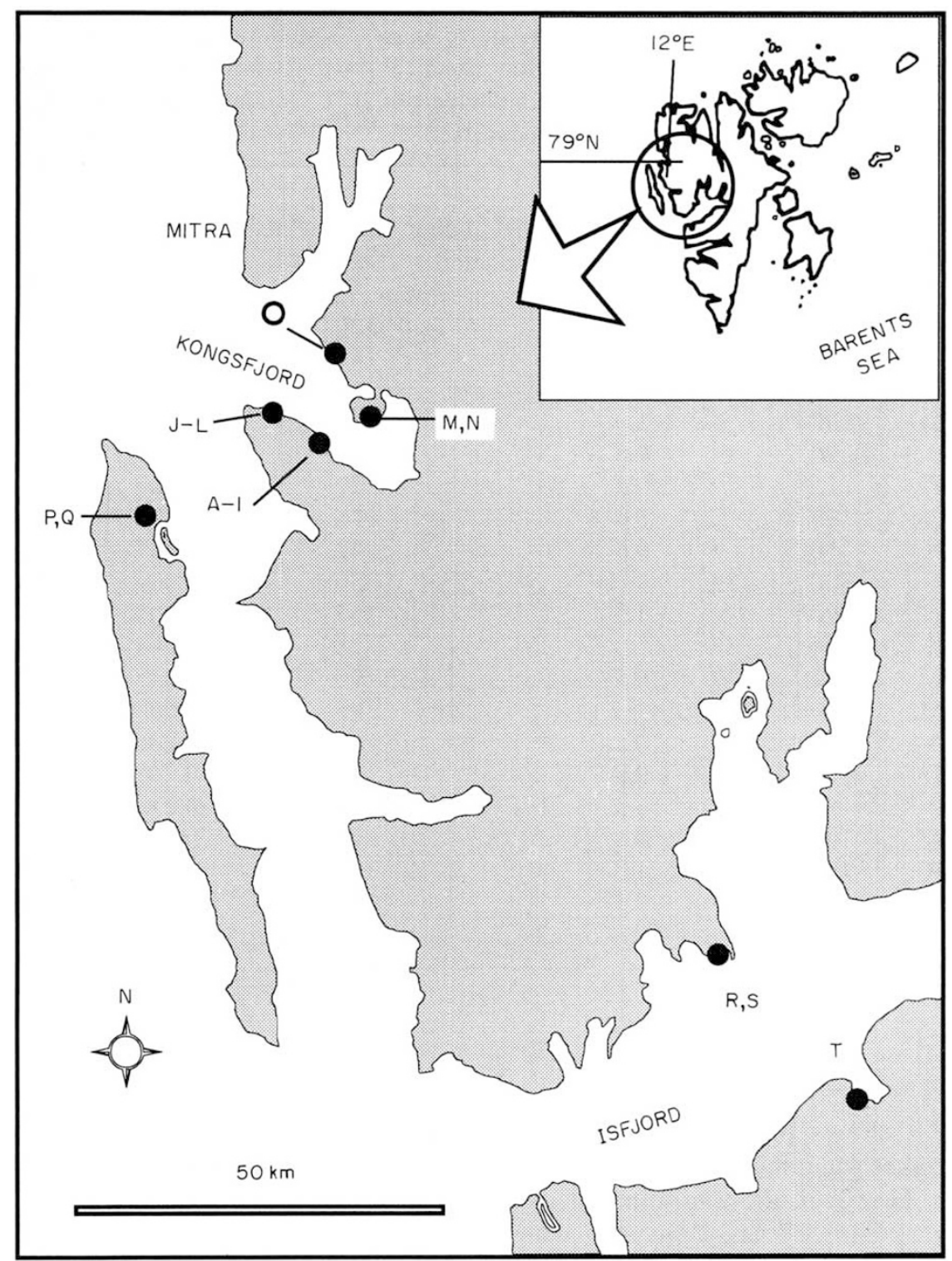

$r=-0.0029$, Mantel $t=-0.036, P=0.49)$ of clonal arrays.

A principal coordinates analysis (Fig. 2) of genetic distances between Svalbard clones indicates that the first three principal axes explain about 73 per cent of the total variation. Electrophoretic clones 6 and 19 are both clearly separated from the others. The former is characterized by unique alleles at $L D H(3)$ and $P G M$ (0). A fairly distinct cluster was formed by clones 9,13 and 20, which were distinct at the $M D H$ locus and occurred only in Pond S. The bulk of clones fell within a diffuse group along principal axis 1 .

\section{Discussion}

The clonal richness of Daphnia pulex (s.l.) in Svalbard ponds (mean 1.7 electrophoretic clones per pond, $N=20$ ponds, 21 clones) is much lower than in similar habitats at a site in the Canadian high-arctic, Igloolik (mean 4.5 clones per pond, $N=179$ ponds, total of 75 clones; Weider et al., 1987a), but is similar to results from a low-arctic site, Churchill (mean 1.5 clones per pond, $N=300$ ponds, total of 16 clones; Weider \& Hebert, 1987a). In Ontario, Hebert \& Crease (1983) found 3.6 clones per pond $(N=11$ ponds, total of 22 clones), while Hebert et al. (1988) found an average of 
Table 1 Localities investigated. Dimensions are field estimates. Vegetation surrounding the ponds is scored as none (0); sparse (1); moderate (2); and rich (3). Mosses dominate vegetation completely, except at pond $\mathbf{T}$, where grasses and sedges dominate. Water quality is given as conductivity at $20^{\circ} \mathrm{C}$, and absorbance at 384 and $254 \mathrm{~nm}$ (unfiltered sample, $1 \mathrm{~cm}$ cuvettes)

\begin{tabular}{lrrlllll}
\hline & & & & & & \multicolumn{2}{l}{ Absorbance } \\
\cline { 7 - 9 } Pond & $\begin{array}{l}\text { Length } \\
(\mathrm{m})\end{array}$ & $\begin{array}{l}\text { Width } \\
(\mathrm{m})\end{array}$ & $\begin{array}{l}\text { Depth } \\
(\mathrm{m})\end{array}$ & $\begin{array}{l}\text { Surrounding } \\
\text { vegetation }\end{array}$ & $\begin{array}{l}\text { Conductivity } \\
\left(\mu \mathrm{S} \mathrm{cm}^{-1}\right)\end{array}$ & & \\
$384 \mathrm{~nm}$ & $254 \mathrm{~nm}$ \\
\hline $\mathrm{A}$ & 30 & 10 & 1.2 & 0 & 320 & 0.004 & 0.028 \\
$\mathrm{~B}$ & 400 & 100 & $>2$ & 1 & 145 & 0.004 & 0.018 \\
$\mathrm{C}$ & 60 & 20 & 1.5 & 1 & 61 & 0.005 & 0.026 \\
$\mathrm{D}$ & 100 & 30 & 1.0 & 1 & 175 & 0.012 & 0.082 \\
$\mathrm{E}$ & 90 & 50 & 0.8 & 3 & 335 & 0.017 & 0.147 \\
$\mathrm{~F}$ & 15 & 8 & 0.4 & 0 & 220 & 0.003 & 0.016 \\
$\mathrm{G}$ & 3 & 2 & 0.4 & 0 & 148 & 0.004 & 0.033 \\
$\mathrm{H}$ & 250 & 70 & 0.6 & 0 & 142 & 0.007 & 0.045 \\
$\mathrm{I}$ & 600 & 400 & $>2$ & 1 & 350 & 0.006 & 0.045 \\
$\mathrm{~J}$ & 400 & 150 & 1.5 & 1 & 155 & 0.000 & 0.012 \\
$\mathrm{~K}$ & 140 & 100 & 1.0 & 1 & 178 & 0.004 & 0.033 \\
$\mathrm{~L}$ & 20 & 20 & 0.5 & 3 & 190 & 0.018 & 0.158 \\
$\mathrm{M}$ & 300 & 100 & $>2$ & 2 & 95 & 0.006 & 0.049 \\
$\mathrm{~N}$ & 80 & 50 & 0.5 & 1 & 180 & 0.006 & 0.062 \\
$\mathrm{O}$ & 150 & 100 & 0.8 & 1 & 132 & 0.005 & 0.049 \\
$\mathrm{P}$ & 80 & 50 & 1.0 & 1 & 200 & 0.016 & 0.077 \\
$\mathrm{Q}$ & 100 & 80 & 0.8 & 1 & 192 & 0.009 & 0.045 \\
$\mathrm{R}$ & 120 & 80 & 1.0 & 3 & 109 & 0.014 & 0.127 \\
$\mathrm{~S}$ & 90 & 50 & 0.5 & 1 & 112 & 0.015 & 0.104 \\
$\mathrm{~T}$ & 15 & 8 & 0.8 & 3 & 470 & 0.022 & 0.083 \\
\hline
\end{tabular}

2.8 clones per pond from 200 ponds in the Great Lakes watershed.

However, the total number of clones at Svalbard is surprisingly high, especially when one considers the few localities sampled and the limited geographic extent of the survey. Extrapolating the data to larger areas is difficult. If the diversity patterns observed are typical of the whole archipelago, then the total number of clones present across the archipelago could be counted in the thousands. However, some clones could be widely distributed and more abundant than is evident from our data. Detection of new clones depends on the number of animals screened per pond, as well as the number of ponds surveyed and presumably the geographic distribution of ponds. By analysing the number of clones detected as a function of these parameters, Hebert et al. (1988) found that asymptotic levels were not easily reached. Moreover, the shape of a clone-area curve differs considerably between regions (Weider \& Hebert, 1987a; Weider, 1989).
The present data set includes too few habitats to indicate this asymptotic level. Nevertheless, it should be noted that every area which was sampled yielded new electrophoretic clones. Data obtained from yet another area (the Mitra peninsula, Fig. 1) in 1986 (Hobæk \& Wolf, unpublished) confirm this trend. Since the Mitra animals were run on starch gels, which produced poor resolution, they were not included in the present data set. At least one of the Mitra clones was not detected elsewhere. If the available data are representative, the present list of distinct clones must be a small subset of a much larger clonal array present in the archipelago.

The lack of geographical patterns in clonal composition of ponds is unexpected. By contrast, Weider (1989) found significant spatial patterns to individual clonal distributions at Igloolik, although many distributions were patchy. While the apparent randomness in distribution may be an effect of too few ponds surveyed, and perhaps too great a spatial scale (on the order of $100 \mathrm{~km}$ maximum distance), the Svalbard ponds are clearly distinguished from previous arctic 
Table 2 Unique composite (7-locus) genotypes (clones) detected at Svalbard 1987 and 1991. Clones are ordered in numerical abundance. Unbalanced electromorphs (see text) are indicated by asterisks, with the 'overrepresented' allele preceding the asterisk. Enzyme abbreviations are given in Materials and methods. '-' denotes missing information

\begin{tabular}{lllllllllll}
\hline Clone no. & $P G M$ & $P G I$ & $A O$ & $G O T$ & $L D H$ & $M D H$ & $M P I$ & $N$ & $\%$ & No. of ponds \\
\hline 1 & $2 * 3$ & 44 & 12 & 23 & 11 & 11 & 34 & 323 & 23.5 & 6 \\
2 & $12 * 3$ & 44 & 12 & 22 & 11 & 11 & 34 & 148 & 10.8 & 3 \\
3 & $2 * 34$ & 44 & 12 & 22 & 11 & 11 & 34 & 146 & 10.6 & 2 \\
4 & 22 & 44 & 11 & 23 & 11 & 11 & 34 & 146 & 10.6 & 2 \\
5 & $12 *$ & 44 & 12 & 22 & 11 & 11 & 34 & 167 & $8.4 \dagger$ & 2 \\
6 & $02 *$ & 14 & 22 & 22 & 33 & 11 & 33 & 77 & 5.6 & 2 \\
7 & $2 * 3$ & 45 & 11 & 22 & 11 & 11 & 34 & 73 & 5.3 & 2 \\
8 & $2 * 3$ & 44 & 11 & 23 & 11 & 11 & 34 & 71 & 5.2 & 1 \\
9 & 22 & 44 & 11 & 23 & 11 & 00 & 22 & 63 & 4.6 & 1 \\
10 & $2 * 3$ & 44 & 12 & 22 & 11 & 11 & 33 & 61 & 4.4 & 1 \\
11 & $2 * 3$ & 44 & 12 & 22 & 11 & 11 & 34 & 56 & 4.1 & 1 \\
12 & $2 * 3$ & 44 & 22 & 22 & 11 & 11 & 33 & 11 & 0.8 & 1 \\
13 & 22 & 44 & 11 & 23 & 11 & 11 & 22 & 8 & 0.6 & 1 \\
14 & $12 * 3$ & 44 & 12 & 22 & 11 & 11 & 44 & 6 & 0.4 & 1 \\
15 & $2 * 3$ & 44 & 22 & 22 & 11 & 11 & 34 & 6 & 0.4 & 1 \\
16 & $2 * 3$ & 14 & 12 & 22 & 11 & 11 & 44 & 5 & 0.4 & 1 \\
17 & $12 * 3$ & 44 & 11 & 22 & 11 & 11 & 34 & 2 & 0.1 & 1 \\
18 & $12 * 3$ & 44 & 12 & 23 & 11 & 11 & 44 & 1 & 0.1 & 1 \\
19 & 22 & $14 *$ & 11 & - & 01 & 11 & - & 1 & 0.1 & $1 \neq$ \\
20 & 22 & 44 & 11 & 33 & 11 & 11 & 22 & 1 & 0.1 & 1 \\
21 & $2 * 3$ & 44 & 33 & 23 & 11 & 11 & 34 & 1 & 0.1 & 1 \\
\hline
\end{tabular}

$\dagger$ Percentage calculated from sample size in 1987 (111 ind.).

$\ddagger$ Only detected in 1991 .

surveys (Weider et al., 1987; Weider, 1989) by containing fewer clones, whose distributions are much more restricted.

An important question remains: Does the observed clonal richness represent well-adapted genotypes that live in ponds with subtle, but important ecological differences, or just a small selection of a much larger clonal array each with rather restricted distributions? In the former case, one would expect a limited number of clones, each of which occurs scattered in ponds over large areas. Also, there should be pronounced differences between clones in competitive abilities, with competitive superiority varying with several ecological factors. Actually, there is considerable evidence that asexual clones of this complex display ecological differences. Such variation has been found in life-history traits like growth rate, reproductive rate, and age at reproductive maturity (Weider, 1987), in osmoregulation (Weider \& Hebert, 1987b) and tolerance to shortwave radiation (Hebert \& Emery, 1990).

In these cases, the distribution of clones among ponds is not random (Weider \& Hebert, 1987b; Hebert \& Emery, 1990). A parallel situation occurs in alpine pond populations of $D$. longispina (Hobæk \& Wolf, 1991). Although we looked for similar patterns at
Svalbard, they were not readily apparent. Ponds did not vary greatly in their conductivity, although absorption in the ultraviolet (UV) range differed markedly between ponds (Table 1). All clones had melanized carapaces, with the exception of clone 6 , which occurred only in Pond M, where animals stayed below $1 \mathrm{~m}$ depth, and in Pond $\mathrm{G}$, in which water was quite turbid (Table 1).

Although environmental heterogeneity may in part support the maintenance of multiclonal populations, it cannot explain all of the variation. For instance, the nearly identical ponds $F$ and $G$, which are situated only $10 \mathrm{~m}$ apart, were inhabited by different clones (Table 3). The most parsimonious explanation for such apparently random occurrences is that stochastic processes (founder effects) coupled with low dispersal rates play an important role not only in structuring clonal distribution patterns in Daphnia, but appear to be critical in gene frequency divergence among other pond-dwelling organisms (Boileau et al., 1991).

Coexistence of multiple, closely related clones in a given homogeneous habitat suggests that competition should be strong, and should presumably result in the competitive exclusion of all but the best competitor. This clearly is not the outcome in many cases (Hebert 
Table 3 Clonal composition of Daphnia pulex pond populations at Svalbard, August 1987. The localities are shown in Fig. 1, and genotypes are listed in Table 2.

$N=$ sample size

\begin{tabular}{|c|c|c|}
\hline Pond & Genotype & $N$ \\
\hline A & 3 & 69 \\
\hline \multirow[t]{2}{*}{ B } & 1 & 71 \\
\hline & 5 & 1 \\
\hline $\mathrm{C}$ & 1 & 75 \\
\hline \multirow[t]{2}{*}{ D } & 2 & 76 \\
\hline & 17 & 2 \\
\hline \multirow[t]{2}{*}{$\mathrm{E}$} & 5 & $166^{*}$ \\
\hline & 19 & $1 \dagger$ \\
\hline F & 1 & 78 \\
\hline G & 3 & 77 \\
\hline \multirow[t]{2}{*}{$\mathrm{H}$} & 11 & 56 \\
\hline & 1 & 22 \\
\hline \multirow[t]{4}{*}{ I } & 2 & 68 \\
\hline & 14 & 6 \\
\hline & 16 & 5 \\
\hline & 18 & 1 \\
\hline $\mathbf{J}$ & 15 & 6 \\
\hline $\mathrm{K}$ & 12 & 4 \\
\hline $\mathrm{L}$ & 12 & 7 \\
\hline $\mathrm{M}$ & 6 & 70 \\
\hline \multirow[t]{2}{*}{$\mathrm{N}$} & 10 & 61 \\
\hline & 2 & 4 \\
\hline $\mathrm{O}$ & 1 & 76 \\
\hline \multirow[t]{2}{*}{$P$} & 4 & 77 \\
\hline & 7 & 2 \\
\hline $\mathrm{Q}$ & 7 & 71 \\
\hline \multirow[t]{2}{*}{$\mathrm{R}$} & 4 & 69 \\
\hline & 6 & 7 \\
\hline \multirow[t]{3}{*}{ S } & 9 & 63 \\
\hline & 13 & 8 \\
\hline & 20 & 1 \\
\hline \multirow[t]{3}{*}{$\mathrm{T}$} & 8 & 71 \\
\hline & 1 & 1 \\
\hline & 21 & 1 \\
\hline
\end{tabular}

*Includes 56 animals sampled in 1991.

$\dagger$ Only detected in 1991 .

\& Crease, 1980; Wilson \& Hebert, 1992). Recent evidence (Weider, 1992) suggests that competitive interactions among clones may be influenced greatly by environmental perturbations, which occur at low to intermediate frequencies, and result in the maintenance of multiclonal populations.

The distributional patterns of clones in different regions are likely a result of both deterministic (e.g. selection) and stochastic (e.g. passive dispersal, founder effects) forces. Given the contrasts in clonal distribution patterns between different regions, and among different organisms (Parker, 1979), further studies of

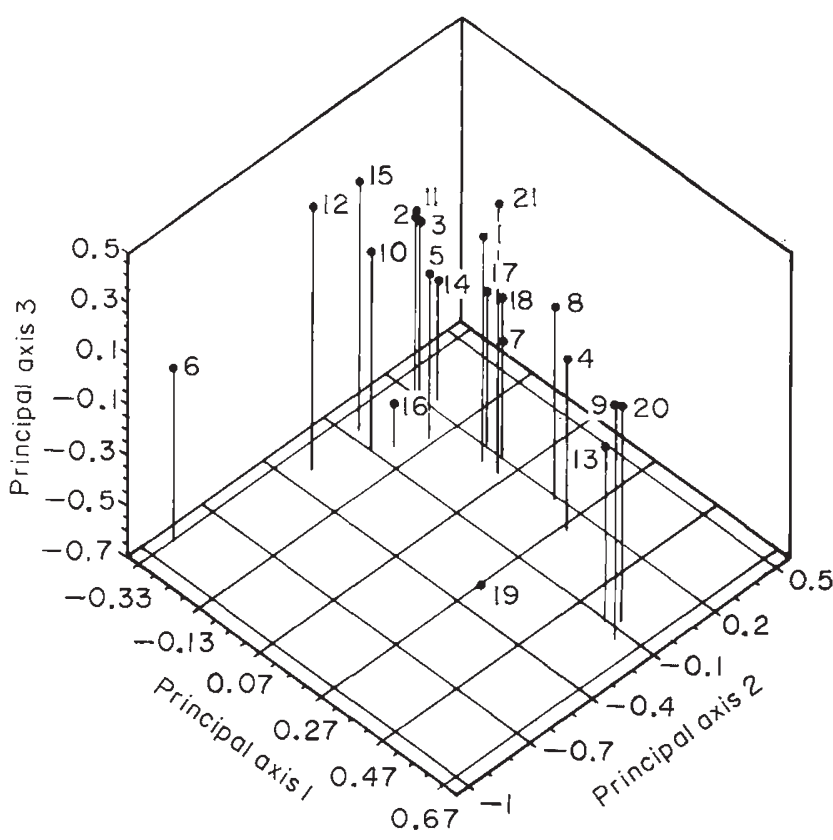

Fig. 2 Three-dimensional plot of the first three principal axes of a principal coordinates analysis of genetic similarity of 21 Daphnia pulex clones. Numbers at each point refer to clonal designations (Table 2).

the factors controlling dispersal and coexistence in asexual complexes should yield interesting results. In particular, more direct measurements of dispersal rates in nature would be valuable (Slatkin, 1987).

One final consideration concerns the taxonomic controversies involving the Svalbard Daphnia pulex complex. The taxonomy of the species complex is presently under revision (Korínek, personal communication), including material from the present study. In the past, Svalbard Daphnia have been designated as Daphnia pulex Leydig (Olofsson, 1918; Thomasson, 1959; Meijering, 1972), Daphnia tenebrosa Sars (Amrén, 1964) and Daphnia middendorffiana Fischer (Brooks, 1957; Halvorsen \& Gullestad, 1976). Based on morphological criteria, clone 6 is probably a true Daphnia pulex (Korínek, personal communication), while the remaining clones belong to $D$. middendorffiana and/or D. tenebrosa. Clone 6 is characterized by allele 3 at $L D H$, while all the other clones had slower alleles at this locus. However, the distinctiveness of these taxa is still uncertain, and must await further morphological and molecular characterization, which we are presently undertaking.

\section{Acknowledgements}

Sampling surveys at Svalbard were made possible by research grants $31 / 86$ and 4/87 from the Norwegian Polar Research Institute. We thank the staff at the 
Research Station in Ny-Ålesund, who were most helpful. We also thank T. Dale and J. Giske for valuable field assistance, E. Geißler for electrophoretic assistance, and H. Sægrov for sampling pond E in 1991.

\section{References}

AMRÉN, H. 1964. Ecological and taxonomical studies on zooplankton from Spitsbergen. Zool. Bidr. från Uppsala, 36, 209-276.

AYRE, D. J. 1987. The formation of clonal territories in experimental populations of the sea anemone, Actinia tenebrosa. Biol. Bull., 172, 178-486.

BEATON, M. J. AND HEBERT, P. D. N. 1988. Geographical parthenogenesis and polyploidy in Daphnia pulex. Am. Nat., 132, 837-845.

BELL, G. 1982. The Masterpiece of Nature; the evolution and genetics of sexuality. University of California Press, Berkeley, CA, U.S.A.

BolleAU, M. G., HEBERT, P. D. N. AND SChwARTZ, s. s. 1991. Nonequilibrium gene frequency divergence: Persistent founder effects in natural populations. J. Evol. Biol., 5, 25-39.

BRooks, J. L. 1957. The Systematics of North American Daphnia. Mem. Conn. Acad. Arts and Sci., Yale University Press, New Haven, CT, 180pp.

CREASE, T. J., STANTON, D. J. AND HEBERT, P. D. N. 1989. Polyphyletic origins of asexuality in Daphnia pulex. II. Mitochondrial-DNA variation. Evolution, 43, 1016-1026.

CHRISTENSEN, B., NOER, H. AND THEISEN, B. F. 1988. Differential responses to humidity and soil type among clones of triploid parthenogenetic Trichoniscus pusillus (Isopoda, Crustacea). Hereditas, 108, 213-217.

FUTUYMA, D. J., LEIPERTZ, S. L. AND MITTER, C. 1981. Selective factors affecting clonal variation in the fall cankerworm. Alsophila pometaria (Lepidoptera: Geometridae). Heredity, 47, 161-172.

GowER, J. C. 1966. Some distance properties of latent roots and vector methods used in multivariate analysis. Biometrika, 53, 325-338.

HALVORSEN, G. AND GULlestad, N. 1976. Freshwater Crustacea from some areas of Svalbard. Arch. Hydrobiol., 78, 383-395.

HANEY, J. F. AND BUCHANAN, c. 1987. Distribution and biogeography of Daphnia in the Arctic. Mem. Ist. Ital. Idrobiol, 45, 77-105.

HEBERT, P. D. N. AND BEATON, M. J. 1989. Methodologies for Allozyme Analysis using Cellulose Acetate Electrophoresis. A practical handbook. Helena Laboratories, 31pp.

HEBERT, P. D. N. AND CREASE, T. J. 1980. Conal coexistence in Daphnia pulex (Leydig): another planktonic paradox. Science, 207, 1363-1365.

HEBERT, P. D. N. AND CREASE, T. I. 1983. Clonal diversity in populations of Daphnia pulex reproducing by obligate parthenogenesis. Heredity, 51, 353-369.

HEBERT, P. D. N. AND EMERY, C. J. 1990. The adaptive significance of cuticular pigmentation in Daphnia. Funct. Ecol., 4, 703-710.
HEBERT, P. D. N., WARD, R. D. AND WEIDER, L. J. 1988. Clonaldiversity patterns and breeding system variation in Daphnia pulex, an asexual-sexual complex. Evolution, 42, 147-159.

HEBERT, P. D. N., BEATON, M. J., SCHWARTZ, S. S. AND STANTON, D. J. 1989. Polyphyletic origins of asexuality in Daphnia pulex. I. Breeding-system variation and levels of clonal diversity. Evolution, 43, 1004-1015.

HOBÆK, A. AND WOLF, H. G. 1991. Ecological genetics of Norwegian Daphnia. II. Distribution of Daphnia longispina genotypes in relation to short-wave radiation and water colour. Hydrobiologia, 225, 229-243.

INNES, D. J., SCHWARTZ, S. S. AND HEBERT, P. D. N. 1986. Genotypic diversity and variation in mode of reproduction among populations in the Daphnia pulex group. Heredity, 67, 345-355.

LYNCH, M. 1983. Ecological genetics of Daphnia pulex. Evolution, 37, 358-374.

LYNCH, M. 1984. Destabilizing hybridization, general-purpose genotypes, and geographical parthenogenesis. Quart. Rev. Biol., 59, 259-290.

MANTEL, N. A. 1967. The detection of disease clustering and a generalized regression approach. Cancer Res., 27, 209-220.

MEIJERING, M. P. D. 1972. Herzfrequenz und Lebensablauf von Daphnia pulex in Spitzbergen. Z. wiss. Zool., 184, 395-412.

olofsson, o. 1918. Studien über die Süsswasserfauna Spitzbergens. Zool. Bidr. Uppsala, 6, 183-646.

PARKER, E. D. JR. 1979. Ecological implications of clonal diversity in parthenogenetic morphospecies. Am. Zool., 19, 753-762.

PIELOU, E. C. 1984. The Interpretation of Ecological Data. John Wiley \& Sons, New York.

ROHLF, F. J. 1990. NTSYs-pc. Numerical taxonomy and multivariate analysis system. Ver. 1.6, Exeter Software, Setauket, New York.

SLATKIN, M. 1987. Gene flow and the geographic structure of natural populations. Science, 236, 787-792.

SNEATH, P. H. A. AND SOKAL, R. R. 1973. Numerical taxonomy. Freeman, San Francisco, CA, U.S.A.

THOMAsson, K. 1959. Zur Planktonkunde Spitzbergens. Hydrobiologia, 12, 226-236.

WARD, R. D. AND GEISSLER, P. A. 1988. Reproductive mode in populations of Daphnia pulex and Daphnia obtusa from the East Midlands of Britain. Freshwater Biol., 20, 69-73.

WEIDER, L. J. 1987. Life history variation among low-arctic clones of obligately parthenogenetic Daphnia pulex: a diploid-polyploid complex. Oecologia (Berlin), 73, 251-256.

WEIDER, L. J. 1989. Spatial heterogeneity and clonal structure in arctic populations of apomictic Daphnia. Ecology, 70, 1405-1413.

WEIDER, L. J. 1992. Disturbance, competition, and the maintenance of clonal diversity in Daphnia pulex. J. Evol. Biol., 5, 505-521.

WEIDER, L. J. AND HEBERT, P. D. N. 1987a. Microgeographic genetic heterogeneity of melanic Daphnia pulex at a lowarctic site. Heredity, 58, 391-399. 
WEIDER, L. J. AND HEBERT, P. D. N. $1987 \mathrm{~b}$. Ecological and physiological differentiation among low-arctic clones of Daphnia pulex. Ecology, 68, 188-198.

WEIDER, L. J., BEATON, M. J. AND HEBERT, P. D. N. 1987. Clonal diversity in high-arctic populations of Daphnia pulex, a polyploid apomictic complex. Evolution, 41, 1335-1346.

WILSON, C. C. AND HEBERT, P. D. N. 1992. The maintenance of taxon diversity in an asexual assemblage: an experimental analysis. Ecology, 73, 1462-1472. 